\title{
The Research on Collaboration Cultivation Mechanism of E-commerce Applied Undergraduate Talents
}

\author{
Xianyong Meng ${ }^{1, \text { a }}$, Yiqi Xiong ${ }^{1, b}$, Xiangyu Meng ${ }^{1, \mathrm{c},{ }^{*}}$, Zhengbo Wang ${ }^{2, \mathrm{~d}}$ \\ ${ }^{1}$ Zhuhai College of Jilin University, Zhuhai, China \\ ${ }^{2}$ Department of Economics and Related Studies, University of York, York, UK \\ a'Meng_xianyong@hotmail.com, ${ }^{b}$ Yiqicolin@126.com, ${ }^{\mathrm{C}}$ Meng_marc@aliyun.com, ${ }^{\mathrm{d}}$ Wang_zhengbo@hotmail.com
}

\begin{abstract}
Through the research on collaboration cultivation mechanism of e-commerce applied talents, this paper is to develop cultivation mechanism of opening, sharing, evaluating for electronic commerce talents, to establish collaboration mechanism of education innovation among SMEs, government agencies, institutions of higher education, and to form a stable system of collaborative education and innovation. The research is helpful to build up the collaboration cultivation platform and resource sharing platform of multiple disciplines, majors, centers and systems on campus, to speed up the integration with e-commerce and other industries, and boost economic structure adjustment, industrial transformation and upgrading of traditional enterprises.
\end{abstract}

Keywords-e-commerce; collaboration cultivation; innovation and entrepreneurship; practice teaching; industrial transformation.

\section{INTRODUCTION}

The common requirements of Opinions on Deepening The Reform of Innovation and Entrepreneurship Education in Universities Issued by General Office of the State Council, The National Medium and Long-term Education Reform and Development Plan Outline (2010-2020), The Long-term Plan for Education Reform and Development of Guangdong Province (2010-2020), and Guangdong Province Twelfth Five-year Plan for National Economic and Social Development Program are to create a collaborative cultivation and innovation mechanism, let theory guide practice, practice stimulates innovation, innovation leads entrepreneurship, entrepreneurship expands employment and to improve the teaching quality of higher education [1].

To improve innovation ability and establish perfect collaborative innovation mechanism is the work center of innovation ability of institutions of higher education promotion plan (also known as the "2011 plan"). Through the research on collaboration cultivation mechanism of ecommerce applied talents, this paper describes how to set up the cultivation mechanism of opening, sharing, evaluating for electronic commerce application talents, to establish collaboration mechanism of education, innovation among SMBs, government agencies, institutions of higher education, and to form a stable system of cooperative education and synergy innovation [2][3]. Therefore, this research is helpful to build up the collaboration cultivation platform and resource sharing platform of multiple disciplines, majors, centers and systems on campus, to speed up the integration with e-commerce and other industries, and boost economic structure adjustment, industrial transformation and upgrading of traditional enterprises [4][5].

From an international perspective, currently, in order to cultivate e-commerce applied talents, universities need to establish e-commerce collaborative education mechanism. In 2013, China's e-commerce transactions reached 10 trillion, more than the United States for the first time, and became the first big country of world's electronic commerce. In the same year, Hangzhou was named one of the first experimental zones of cross-border e-commerce trade and was elected as demonstration area of e-commerce by the relevant ministries and commissions of the state as well, which marked the internationalization of e-commerce transactions and e-commerce talents [6][7].

Domestically, in order to cultivate innovative talents of e-commerce, universities need to establish e-commerce collaborative education mechanism. In the future, ecommerce will create more new business models and stimulate the enterprise transformation through system innovation, management innovation, service innovation and collaborative development. At present, some colleges and universities carry out the e-commerce innovative talents cultivation via the cooperative education platform among schools, governments, and enterprises. Also, through the perspective on the future of electronic commerce, traditional enterprise e-commerce operation models are innovated.

As for Guangdong Province, in order to cultivate operation talents of e-commerce, universities need to establish e-commerce collaborative education mechanism. The pearl river delta region requires a lot of e-commerce operation and management talents, at present, some colleges and universities cultivate e-commerce operations and management talents to meet the needs of the development of regional economy and society via the cooperative education platform among schools, governments, and enterprises.

Therefore, institutions of higher education strive to develop the collaborative education platform among schools, governments and enterprises, and cultivate applied and innovative talents of electronic commerce, and take advantage of innovating operation management model, improving the efficiency of industrial organization, and activating market vitality. Colleges and universities also 
need to cultivate e-commerce talents for planning, designing, implementation, operation and management who are able to work across platforms, disciplines, different centers and majors, and according to the regional economic and social development needs, try to adjust the teaching plan to improve the quality of practice teaching. At the same time, through the electronic commerce applied talents collaborative training mechanism innovation, colleges and universities could set up e-commerce applied talents cultivation mechanisms of opening, sharing, evaluating. For implementation of e-commerce applied talents training mechanism, incentive mechanism, and entrepreneurial mechanism, it is needed to cultivate innovative high-quality talents to provide e-commerce services for the regional economic and social development [8][9].

\section{Estabish A Practice Teaching Platform For E- COMMERCE COLLABORATIVE EDUCATION}

The innovation of e-commerce applied talents collaborative cultivation mechanism is to establish a practice teaching platform of multiple disciplines, majors, centers, and systems on campus. E-commerce collaborative education and practice teaching platform mainly consists of four different parts.

\section{A. Course Experiment, Practical Training Platform}

According to the training target of e-commerce applied undergraduate talents, experimental courses and experimental projects are designed and developed to improve the quality of experiment teaching and cultivate students' practice ability and innovation ability.

\section{B. Extracurricular Experiment, Practical Training Platform}

The main purpose of laboratory and training platform on campus is to expand the students' extracurricular training space, cultivate the students' practical ability and team cooperation ability and innovation ability, at the same time, improve the efficiency of resource utilization as well..

\section{Innovation and Entrepreneurship Platform Base on High Quality Education Resources of Internet}

Based on high quality education resources of Internet like mooc class, excellent class and national essential class, the research on practice teaching and collaborative cultivation mechanism of e-commerce applied talents is conducted..

\section{Collaborative Cultivation Platform among Schools, Governments and Enterprises}

Colleges and universities build laboratory and practice base with small and medium-sized enterprises and government agencies, and carry out training and practice teaching using social high quality education resources to do practical training and teaching.

Among them, in the small and medium-sized enterprises, government agencies, and universities, the key of e-commerce applied talents cultivating mechanism innovation is to establish the collaborative education, innovation and business incubation mechanism of ecommerce talents based on the high quality education resources of Internet.

\section{RESEARCH METHOD}

\section{A. Clearing Related Development Plans and Outlines}

Making sure clear research purpose and combing national and regional development plans and outlines, main related programs include:

- Opinions on Deepening The Reform of Innovation and Entrepreneurship Education in Universities Issued by General Office of the State Council

- Institutions of Higher Education Innovation Ability Enhancement Plan

- The National Medium and Long-term Education Reform and Development Plan Outline (2010-2020)

- Guangdong Province Twelfth Five-year Plan for National Economic and Social Development Program

- The Twelfth Five-year Development Planning of Ecommerce of Guangdong Province

\section{B. Establish E-commerce Collaborative Cultivation} Mechanism According to the Regional Economic and Social Development Needs

According to needs on the regional economic and social development of electronic commerce talents, it is to develop the teaching goal, teaching content, teaching method, practice environment, the evaluation standards and management practices of e-commerce applied talents cultivation mechanism, and to determine the mechanisms of opening, sharing, evaluating of e-commerce applied talents. At the same time, quantify the evaluation index of collaborative cultivation mechanism in order to accurately measure the effect of collaborative education management.

\section{Design Collaboration Cultivation Mechanism of E- commerce Applied Talents}

The correct, feasible, scientific and efficient ecommerce applied talents collaboration cultivation mechanism consist of collaborative education teaching content, evaluation content, evaluation method, evaluation cycle, organization form, organization scale, collaborative approach, good example model, teaching methods, teaching management strategy, collaboration mechanism and evaluation mechanism, etc.

\section{THE RESEARCH ON COLlaboration CUltivation MECHANISM OF E-COMMERCE APPLIED UNDERGRADUATE TALENTS}

The overall framework and the basic research content are as follows:

\section{A. Innovation of Teaching Methods of Collaboration Cultivation Mechanism}

Based on high quality education resources of Internet, the research on innovation of collaborative cultivation mechanism of e-commerce applied talents is conducted. In 
order to innovate teaching methods, colleges and universities, government and enterprises carry out the network collaborative teaching methods research through the cooperative education platform of economic and management experiments and practical training platform. The research is to nurture electronic commerce management talents for "pearl river delta" regional economic and social development, as well as " pearl river delta "advantage industries deepening e-commerce applications, international trade enterprises to carry out cross-border e-commerce and transformation of SMEs management model.

\section{B. Innovation of Teaching Management of Collaboration Cultivation Mechanism}

Based on high quality education resources of Internet, the research on innovation of collaborative cultivation mechanism of e-commerce applied talents is conducted. The teaching management standards on teaching methods of electronic commerce practice teaching include the standardization of the practice teaching content, modules, projects, assessment, innovation ability cultivating model and business incubation process, etc.

\section{Teaching Goals of Collaboration Cultivation Mechanism}

The teaching goals are that institutions of higher education strive to develop the collaborative education platform among schools, governments and enterprises, and cultivate applied and innovative talents of electronic commerce. Taken full advantage of high quality education resource of Internet, it is helpful to build up the collaboration cultivation platform and resource sharing platform of multiple disciplines, majors, centers and systems on campus, to speed up the integration with ecommerce and other industries, and boost economic structure adjustment, industrial transformation and upgrading of traditional enterprises.

\section{Innovation and Entrepreneurship Ability of Collaboration Cultivation Mechanism}

Based on the Internet and collaborative education platform built by Colleges and universities, governments, enterprises, dominated by innovative practice teaching, and practice teaching, the constructions of cross-disciplines, cross-platform, cross-major collaborative innovation ability cultivation mechanism and entrepreneurial ability cultivation mechanism are realized.

\section{E. Integration and Utilization of High Quality Education Resources of Internet}

In-depth research and analysis of the characteristics of the network teaching resources could help effectively integrate and utilize e-commerce practice teaching resources in "Ali ecosystem" and "Tencent WeChat platform", and establish network education resources sharing platform and practical training platform of ecommerce applied talents collaborative cultivation mechanism.

\section{F. The Research on Talent Cooperative Cultivation Model}

Based on high quality network teaching resources, to establish a trinity model of e-commerce applied talents collaborative cultivation includes course experiments, practical training, economic and management comprehensive experiments, and practical training model of universities, governments and enterprises. The ultimate goal is to build establish the guidance mechanism of independent learning, incentive mechanism of innovation, and the cultivation mechanism of entrepreneurship.

\section{V.CONCLUSIONS}

Through the research on collaboration cultivation mechanism of e-commerce applied talents, this paper is to set up the cultivation mechanism of opening, sharing, evaluating for electronic commerce application talents. The research is helpful to build up the collaboration cultivation platform and resource sharing platform of multiple disciplines, majors, centers and systems on campus, to cultivate applied and innovative talents of electronic commerce, and take advantage of innovating operation management model, improving the efficiency of industrial organization, and activating market vitality, and to speed up the integration with e-commerce and other industries, and boost economic structure adjustment, industrial transformation and upgrading of traditional enterprises.

\section{REFERENCES}

[1] Abrahams, Alan, Singh, Tina. 2010. An Active, Reflective Learning Cycle for E-Commerce Classes: Learning about E-commerce by Doing and Teaching. Journal of Information Systems Education 21(4): 383390

[2] Ann-Marie Lynam, Clare Corish, Deirdre Connolly. 2015. Development of a framework to facilitate a collaborative peer learning 2:1 model of practice placement education. Nutrition \& Dietetics 72(2): $170-175$

[3] Eric W. T. Ngai. 2004. Teaching an learning of e-commerce at the Hong Kong Polytechnic University: from business education prospective. Journal of Electronic Commerce in Organizations 2(2): 21-32

[4] W. T. Ngai, S. S. Lam, J. K. L. Poon. 2013. Successful implementation of a computer-supported collaborative learning system in teaching ecommerce. International Journal of Information and Communication Technology Education 9(4): 1-20

[5] Fabio Alivernini, Radka Wildova. 2013. The implications of international collaborative partnerships and within higher education institutions. Procedia - Social and Behavioral Sciences 84: 1444-1447

[6] Jenny Yiend,Saranne Weller,Ian Kinchin. 2014. Peer observation of teaching: The interaction between peer review and developmental models of practice. Journal of Further and Higher Education 38(4): 32-35.

[7] Marjan Laal, Zhina Khattami-Kermanshahi, Mozhgan Laal. 2014. Teaching and Education; Collaborative Style. Procedia - Social and Behavioral Sciences 116: 4057-4061

[8] Sanja Mohorovičić, Edvard Tijan, Dragan Čišić. 2010. Using web content management systems in university e-commerce courses. International Journal of Emerging Technologies in Learning 5(2): 38

[9] Xinwei Zheng. 2012. Information-based study of e-commerce website design course. Journal of Software 7(12): 2794-2799 